\title{
TÖRÖK FÜRDŐKULTÚRA MAGYARORSZÁGON
}

\section{TURKISH BATH CULTURE IN HUNGARY}

\author{
Bodolai Henrietta $^{1}$, Kósa Balázs ${ }^{2}$, Molnár Tamás ${ }^{3}$, Szücs Gábor Arnold ${ }^{4}$ \\ ${ }^{1}$ Pécsi Tudományegyetem Müszaki és Informatikai Kar Vizuális Ismeretek Tanszék, \\ Cím:Magyarország, 7624 Pécs Boszorkány út 2.; Telefon: +36-30-333-6838, \\ Magyarország, 7400 Kaposvár Toponári út 74., bodolai.henrietta.heni@gmail.com \\ ${ }^{2}$ Pécsi Tudományegyetem Müszaki és Informatikai Kar Vizuális Ismeretek Tanszék, \\ Cím:Magyarország, 7624 Pécs Boszorkány út 2.; Telefon: +36-30-539-9616 ko- \\ sa.balazs.84@gmail.com \\ ${ }^{3}$ Pécsi Tudományegyetem Müszaki és Informatikai Kar Vizuális Ismeretek Tanszék, \\ Cím:Magyarország, 7624 Pécs Boszorkány út 2.; Telefon: +36-70-338-3183 \\ tmolnar@mik.pte.hu \\ ${ }^{4}$ Pécsi Tudományegyetem Müszaki és Informatikai Kar Vizuális Ismeretek Tanszék, \\ Cím:Magyarország, 7624 Pécs Boszorkány út 2.; Telefon: +36-30-570-9349, \\ Magyarország, $8400 \quad$ Veszprém Haszkovó utca 35/D., \\ szucs.gabor.arnold@gmail.com
}

\begin{abstract}
Just like at the Romans, the bath was the main venue of everyday life for the Turkish people as well. Besides that woman exchanged recipes, they gave advices to each other, the man disputed important issues and often kept pre-arranged marriages here. You were only allowed to pray, when you are properly cleaned. Of course, it is not negligible that the construction of baths was in many cases intended to promote material well-being, as they were usually built by senior executives who influenced the satisfaction of their followers in a very positive direction. Generally speaking, these baths were free for the reasons mentioned above, indicating to everyone that the builder was a wealthy man.
\end{abstract}

Keywords: turkish,, Pécs, monumental building, ilidzse, hammam.

\section{Összefoglalás}

Ahogy a rómaiaknál, úgy a török népnél is a fürdő a mindennapi élet fö színhelye volt. Mindamellett, hogy a nők recepteket cseréltek, tanácsokat adtak egymás számára, a férfiak fontos kérdéseket vitattak meg és nagyon sokszor elrendelt házasságokat kötöttek ezeken a helyeken, vallási szempontból is jelentőséggel bírtak. Imádkozni ugyanis, csak tisztán volt szabad. Természetesen az sem elhanyagolható tény, hogy a fürdők építése sok esetben az anyagi jómódot volt hivatott hirdetni, hiszen általában magasabb vezetői pozícióban lévők építtették őket, mely követői elégedettségét rendkívül pozitív irányba befolyásolta. Általában ezek a fürdők az előbb említett okokból adódóan ingyenesek voltak, ezzel is jelezve mindenki felé, hogy az építtető tehetős volt.

Kulcsszavak: török, Pécs, müemléki épület, ilidzse, hammam. 


\section{Történelmi áttekintés}

A víz már az ősidőktől kezdve jelen volt az emberek életében, hiszen a vízben rengeteg élőlényt találhatunk, amiket őseink táplálék gyanánt ismertek, ezenkívül tökéletes közlekedési felület is. Már az ókori kultuszokban jelentős szerepe volt. Szinte minden vallás megemlíti, használja a fürdést. Legtöbbször a test mellett a lélek megtisztulását jelképezi és talán pont ez az, ami elindította a fürdőkultúrát. Tehát az oka, amiért az emberek kezdetekben elkezdtek mosdani, az a víz tisztelete, természetfeletti eröt tulajdonítottak neki, rituális mosdásokhoz használták. Wirth István így ír róla Fürdőkultúra címü publikációjában: „A fürdök az ókori keleten kultikus és gyógyászati szerepet töltöttek be. A legismertebb a bibliai Beteszda Jeruzsálemben a tó fölé, melyet a gyógyító víz táplált öt oszlopcsarnokot építettek, a betegek itt feküdtek és várták, hogy a tóra leszálló Úr angyala felkavarja a vizet és az elsöként vízbelépők meggyógyultak. Talán az idönként újra és újra feltörö viznek tulajdonítottak nagyobb hatást. A hagyomány szerint itt fürdették az áldozati bárányokat a templomi szertartás elött. Az idöszámitás kezdetén már szent helyként tartották számon. Itt végezte Jézus a nyomorék ember gyógyítását."[1] Ma már természetesen kinőtte magát és nem csak a különböző vallásról szól. Jelenünkben ott van a szórakozásban, kikapcsolódásban, sportban, gyógyításban, úgy alapvetően a mindennapjainkban.

Kialakulásuk történelmében jelentős szerepe van a török kultúrának. Mai napig sok ilyen jellegü fürdővel találkozhatunk ország majdnem minden területén. Nem megszokott kinézetük miatt könnyen észrevehető, a mai rohanó világban mégis legtöbben elsétálnak mellettük, ezért döntöttük amellett, hogy egy ilyen gyöngyszemet kiemelünk városunk, Pécs házrengetegei közül.
Alapvető szabálya a török fürdőknek sok helyen még napjainkban is így üzemel hogy a nők és a férfiak nem tartózkodhattak egyszerre az épület területén, így két eshetőség volt elképzelhetö. Az egyik, hogy a hetet beosztva adott napokon csak a hölgyek, más napokon a férfiak látogathatták az ilyen típusú intézményeket, a másik pedig, hogy ún. ikerfürdőket hoztak létre. Ilyen volt a pécsi Memi pasa fürdője is, amellyel tanulmányunkban később részletesen is foglalkozunk. Kétféle típusát különböztetjük meg felépítésük és funkciójuk szerint a török fürdőknek. Egyik az ilidzse, azaz termál, a másik pedig a hamam, azaz gőzfürdő. Lényegében, hogy melyik típusról eshet szó egy adott fürdőnél azt a körülötte lévő környezeti adottságok határozzák meg. Ha volt a közelben termálvízű forrás, akkor általában ilidzse kapott helyet. Ilyenkor nem csak a fal- és padlófütés vezetékeiben keringették ezt a vizet, ezzel befútve a fürdőt, hanem a kör, szabályos sokszög alakú forró helyiségben medencét építettek be. Ahol nem állt rendelkezésre efféle forrásvíz, ott kénytelenek voltak kazánnal füteni és az ott keletkező forró levegőt keringették a rendszerben. Itt nem volt medencére lehetőség. Falikutakat és mosdó medencéket építettek, amikből folyó vízzel sokszor fellocsolták a padlót, hogy a forróságot a keletkező gőzzel ellensúlyozzák. Felépítésük szerint egy ilyen fürdő három részből épült fel: A bejárat maga az öltöző terem volt. Ez után következett az átmeneti helyiség, ahol általában körben padok voltak kialakítva, megszakítva néhány falikúttal, ami saját testük locsolására, illetve a felmelegedett falak, padlózat locsolására használtak. A tradicionális gőzfürdők következő helyisége a forró terem volt, ahol a rituálék folytak. Itt a terem közepén egy köldökkő elnevezésű kőlapot fektetek le, amire ráfeküdve a kliensek megkapták a fürdőmesterektől a masszázsokat, kezeléseket. Ezenkívül a falak mentén szintén megtalálhatóak voltak padok és falikutak hütésre. A gőz- 
fürdőknél a termálvíz hiánya miatt, szükség volt afféle kazánház, víztároló kialakítására, ez általában fürdőtértől elválasztva állt, ahonnan a forró levegő a padló alatt elhelyezkedő fütőrendszerbe áramlott.

\subsection{Memi pasa fürdője - történet}

Evlia cselebi történetmondó, aki rengeteget utazott az akkori török hódoltság területein 1663-ban Pécsen is járt. ,,Fürdője három van... A Szigetvári kapun belül Memi pasa dsámija közelében van Memi pasa fürdöje, kellemes, szép épületü meleg fürdö, melynek fürdöszolgái, mint a nap, olyan tenyerüek." [2] Leírásaiban három fürdőt említ meg itt Pécsen, egyik Ferhád pasa fürdője (ma már nem látható), másik Kászim pasa fürdője (szintén nem maradt fent) és egy harmadikat, Memi pasa fürdöjét. Ez utóbbi kb. az 1880-as években elpusztult, de később, amikor feltárták az akkori Sallai utca teresedését, akkor bukkantak rá az ikerfürdő egy részére. Ez hamamként, azaz gőzfürdőként funkcionált, mivel a közelben nincs meleg vizü forrás. Körülbelül a 16. század második felében épülhetett, Memi pasa küllijének (több épületből álló komplexum) része volt. A szigeti kapu közelében a városfalon belül helyezkedett el, közvetlenül a Ferences templom (akkori Memi pasa dzsámi) szomszédságában. A feltárást Gerő Győző végezte: „Memi pasa fürdojjének feltárt maradványa kelet-nyugati irányban elhelyezkedö hosszanti téglalap alaprajzú építmény melynek hossza 29,13 m, ismert legnagyobb szélessége pedig 11,60 m."[3]. A részlegeges rekonstrukciót Dr. Bachman Zoltán készítette, ahol a megtalált falakat, eredeti padlózatot, és egyéb hozzátartozó részeit szerették volna bemutatni. Az előtérben például egy hatszögletü csorgó kutat is megjelenítettek. A falak mellett megtalálhatóak azok az ülöpadok, szófák, amiken pihenhettek A langyos helyiségben a falikút és ugyancsak az imént említett ülöalkalmatosságok. A legbelső, azaz a forró helyiség padlózata nem maradt fent. A feltárás során, a falakon kirajzolódott vonalából, illetve a padlófütés tégla pillérjeiből tudták mindöszsze megállapítani, hogy is lehetett és azt az állapotot álították helyre. Ezen kívül itt is szintén találhatóak voltak falikutak, mosdómedencék, amiből folyó vízzel felforrt testüket hütötték le, és a legfontosabb, a nyolcszögalakú köldökkő a padlózaton, ahol az akkori vendégeket masszírozták. A fürdőhelyiségek mellett a kazánház és a fütőhelyiség részletei is felszínre kerültek. Ez a későbbiekben kiállítótérként funkcionált. Ezeket a helyiséget kupola fedte, amiket szabályos hatszög alakú nyílások lyuggattak ki. Ez szimbolizálta a csillagos eget számukra.

\section{Fejlesztési koncepció}

Az épület romjainak pontos dokumentálása, geometriai felmérésén túl, feladatunknak éreztük, hogy egy állagmegóvó és újra hasznosító munkát is elvégezzünk, koncepcionális szinten. Fontosnak gondoltuk egy olyan hozzáépítés tervének elkészítését, ami, mint egy burok védi a maradványokat, nem túl agresszív, de mégis kellően határozott tömegformálású ahhoz, hogy felhívja a figyelmet a Ferencesek utcájában szunnyadó müemlékre. Koncepcionális szempont volt az is, hogy mindenki számára egyértelmủ legyen az adott müemlék keletkezésének kora, így jellegzetes motívumokban és tömegkialakításban gondolkodtunk. Ebböl adódóan egy fémszerkezet került az üvegsipka alá, amelyek a falakon lévő védőbeton rétegre terhelnek rá, ezzel egy olyan homlokzatot képezve, ami figyelemfelhívó, mégis diszkrét. A szerkezet alapmotívumát egy hétköznapi iszlám mintából finomítottuk, képeztük le. Az egész szerkezetet homok fúvott üvegburokkal borítottuk, ezzel védelmet adva a romoknak és sejtelmességével a hamam jellegére, hangulatára igyekeztünk utalni. Ha már elértük, hogy a járókelők meg akarják ismerni a 
fürdő maradványait, bemenjenek a megmaradt falai közé, szükségünk volt egy megfelelö információs közegre. Járófelületének egy nyomásérzékelőkkel ellátott üvegfödémet képzeltünk el, ahol a lépések hatására bekapcsolnak a LED-égős él-világítók egyegy mezőben és így láthatóvá válik több nyelven információ a fürdőről, amely anyagában mart, homokfúvással készült üveg volna. A víztiszta üveg lehetővé teszi, hogy a meglévőség jól látható maradjon mindezek ellenére. Ezen eszközök segítségével olyan hatást szerettünk volna elérni, amely nyomot hagy az emberekben, és más ehhez hasonló műemlékeket is szívesen megismer később.

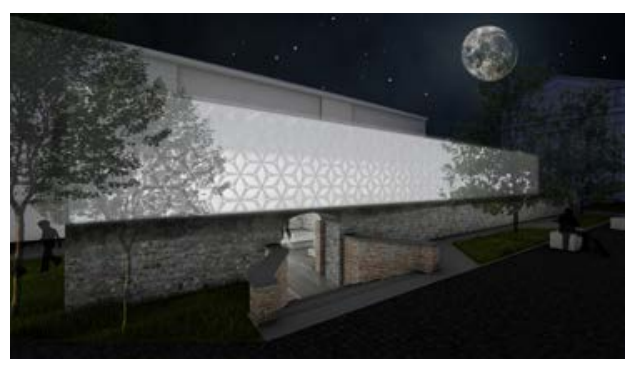

1. ábra. Ötletterv éjszakai látványa (saját készités)

\section{Következtetések}

Véleményünk szerint megismervén ezeknek a fürdőknek a történelmét, hogy az őskor óta mit miért teszünk, mennyi félefajta okból használjuk a mosdást már értékesnek mondanánk a kutatásunkat. A törté-

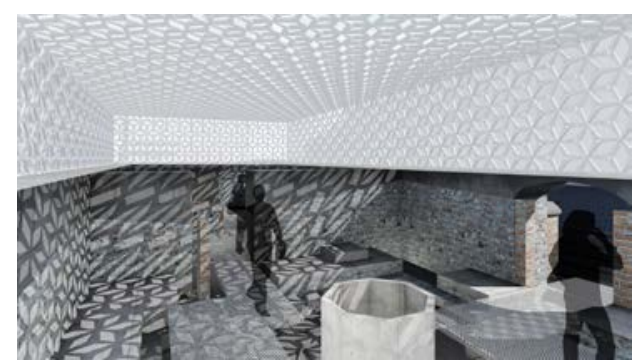

2. ábra. Ötletterv belső látványa (saját készítés)

nelme összehasonlítva az elmúlt időkkel észrevettük, hogy nem is olyan nagy a különbség a mai kor fürdőkultúrája körül. Látván a megmaradt fürdőket milyen nagy becsben tartották az elmúlt évszázadokban és a mai napig is, amelyiket lehet, megmentik és felújítják. Érezhetjük, hogy a mai kor emberének is épp úgy fontosak. Természetesen ma már a fürdőkultúra fogalma eléggé kitárult és belépett a társadalmunk mindennapjai közé. Azt gondoljuk, meglévő török fürdő épületeinket pont ezért kell felújítgatni, hisz ugyan egy más nép tollvonása, de a mi papírunkon.

\section{Szakirodalmi hivatkozások}

[1] Wirth I.: Fürdökultúra. Szent István Egyetem, 2011, 2.

[2] Evlia Cs.; Karácson I.: Evlia Cselebi török világutazó magyarországi utazásai 1660 1664. Magyar Tudományos Akadémia, Budapest, 1904, 201.

[3] Gerő Gy.: A pécsi Memi pasafürdö. Műemlékvédelem, 1987, 112. 